\title{
The ecological role of extremely long-proboscid Neotropical butterflies (Lepidoptera: Hesperiidae) in plant-pollinator networks
}

\author{
J. A.-S. Bauder ${ }^{1}$ A. D. Warren ${ }^{2}$ H. W. Krenn ${ }^{1}$
}

Received: 30 August 2014/ Accepted: 8 April 2015/Published online: 2 June 2015

(C) The Author(s) 2015. This article is published with open access at Springerlink.com

\begin{abstract}
Extremely long proboscides of insect flower visitors have been regarded as an example of a coevolutionary arms race, assuming that these insects act as efficient pollinators for their nectar host plants. However, the effect of proboscis length on generalized or specialized flower use remains unclear and the efficiency of butterfly pollination is ambiguous. Neotropical Hesperiidae feature a surprising variation of proboscis length, which makes them a suitable study system to elucidate the role of extremely long-proboscid insects in plant-pollinator networks. The results of this study show that skippers with longer proboscides visit plant species with deep-tubed flowers to take up food, but do not pollinate them. Skippers equipped with extremely long proboscides seldom include short-tubed flowers in their diet nor visit more plant species than those with shorter proboscides. Our observations indicate that the extremely long-proboscid skippers steal nectar from their preferred nectar host plants, Calathea sp., instead of contributing to their pollination. Finally, we discuss the impact of nectar robbery by these butterflies on their nectar host plants and their legitimate pollinators, euglossine bees.
\end{abstract}

Keywords Skippers $\cdot$ Calathea $\cdot$ Insect-plant interaction $\cdot$ Foraging behavior $\cdot$ Coevolution

Handling Editor: Katja Hogendoorn.

J. A.-S. Bauder

julia.bauder@univie.ac.at

1 Department of Integrative Zoology, University of Vienna, Vienna, Austria

2 McGuire Center for Lepidoptera and Biodiversity, Florida Museum of Natural History, University of Florida, Gainesville, FL, USA

\section{Introduction}

Many scientists have pondered over the evolutionary processes that led to the development of particularly elongate proboscides in flower-visiting insects (Darwin 1862; Johnson 1997; Johnson and Anderson 2010; Muchhala and Thomson 2009; Nilsson 1988, 1998; Pauw et al. 2009; Rodríguez-Gironés and Llandres 2008; Rodríguez-Gironés and Santamaría 2007; Wasserthal 1997, 1998; Whittall and Hodges 2007). The most widely accepted hypothesis for the evolution of extreme mouthpart lengths is that they coevolved with long nectar spurs of angiosperms. In this way, the plant partner secures its pollination and the insect partner gains exclusive access to plenty of nectar (Darwin 1862; Nilsson 1998).

Although the majority of butterflies feed on floral nectar (Krenn 2010), their role as effective pollinators remains doubtful in many examples (Courtney et al. 1982; Wiklund 1981; Wiklund et al. 1979). A mutualistic coevolutionary relationship between particular butterfly species and their preferred nectar host plants has only been demonstrated in two cases (Gilbert 1972, 1975; Grant and Grant 1965; Levin and Berube 1972). In fact, some authors regard butterflies as opportunistic flower visitors that use resources as they become available during the season (Shreeve 1992; Stefanescu and Traveset 2009; Tudor et al. 2004). The effect of proboscis length on generalized or specialized flower use remains contradictory and to date has been investigated mainly in temperate butterfly communities (Corbet 2000; Porter et al. 1992; Stefanescu and Traveset 2009; Tiple et al. 2009; Tudor et al. 2004).

Here, we investigated Neotropical skipper butterflies (Hesperiidae) with a wide range of proboscis lengths to test the hypothesis that insects equipped with extremely long mouthparts specialize on flowers with deep nectar spurs. 
Alternatively, the hypothesis could be forwarded that extremely long-proboscid butterflies use a wide variety of flowers regardless of nectar spur length in an opportunistic way: The longer the proboscis, the more flowers which can be visited. Finally, we raise the question whether extremely long-proboscid butterflies act as pollinators of their nectar plants and thus constitute another example of a coevolved pollination mutualism, as in extremely long-proboscid hawk moths and orchids.

\section{Materials and methods}

\section{Flower use, study area and species sampling}

We chose four flowering plant species (Verbenaceae: Lantana camara, Stachytarpheta frantzii; Marantaceae: Calathea crotalifera, Calathea lutea) growing in the garden and surroundings of the Tropical Station La Gamba (Costa Rica, Puntarenas, Piedras Blancas National Park, $8^{\circ} 45^{\prime} \mathrm{N}, 83^{\circ} 10^{\prime} \mathrm{W} ; 81 \mathrm{~m}$ a.s.l.) for recording skipper visitation (Fig. 1a, b) during an overall observation time of approximately $240 \mathrm{~h}$ (September-October 2012, JanuaryFebruary 2013). All four plant species flowered during both observation periods in the seminatural garden area, which borders on natural forest habitats. The plant species grew in close proximity to each other and within reach of the butterfly species foraging in this area. The study area offers a rich nectar supply throughout the year that is highly attractive to a great variety of butterflies colonizing the surrounding natural and seminatural habitats (Krenn et al. 2010). The four studied flowering plant species make different demands on their visitors due to their varying corolla lengths. Therefore, the observation of butterflies visiting these flowers allows for drawing conclusions on the flower morphology preferences, i.e., corolla length, of butterflies with varying proboscis lengths.
Skippers were collected with a hand net after they landed on flowers and subsequently uncoiled the proboscis. Specimens were stored in $70 \%$ ethanol. Classification of taxa follows the recent phylogeny of Hesperiidae (Warren et al. 2009).

\section{Measuring proboscis length}

Proboscis length of ethanol-preserved specimens was measured. The proboscis of each specimen was separated from the head at its base, uncoiled and fixed on a foam mat using insect pins. Micrographs of the proboscis were taken using a Nikon SMZ 1500 stereomicroscope (Nikon, Tokyo, Japan) equipped with an Optocam-I digital camera (Nikon, Tokyo, Japan). Micrographs were imported to ImageJ (US National Institutes of Health, Bethesda, USA), and proboscis length was measured with the aid of the segmented line tool. The proboscis lengths of skippers caught in September-October 2012 and January-February 2013 did not differ significantly (Mann-Whitney $U$ test $\mathrm{Z}=-0.422, p=0.67, N=148$ ). Therefore, the data collected in 2012 and 2013 were pooled for all further analyses.

\section{Floral biology and corolla length}

The small flowers of $L$. camara (Verbenaceae) are mostly yellow or orange in color, changing to red or scarlet with age, and form a slightly curved corolla tube (Fig. 2). They are arranged in hemispheric inflorescences, up to $3 \mathrm{~cm}$ wide, that can be used by butterflies as a landing platform (Woodson et al. 1973).

The flowers of S. frantzii (Verbenaceae) are larger than those of L. camara and are colored purple (Fig. 2). The corolla is fused to a slender cylindrical tube which is semiimmersed in the rachis of spikes. The flowers are arranged in terminal inflorescences (Woodson et al. 1973).
Fig. 1 Neotropical skippers with different proboscis length use flowers with matching nectar spur length. a Papias $c f$. phainis (Godman 1900) with a medium-sized proboscis visits flowers of $S$. frantzii (Verbenaceae). Image courtesy of M. Hepner. b The extremely long-proboscid skipper Carystoides escalantei $\mathrm{H}$. Freeman 1969 drinks nectar from a long-spurred flower of $C$. lutea (Marantaceae)
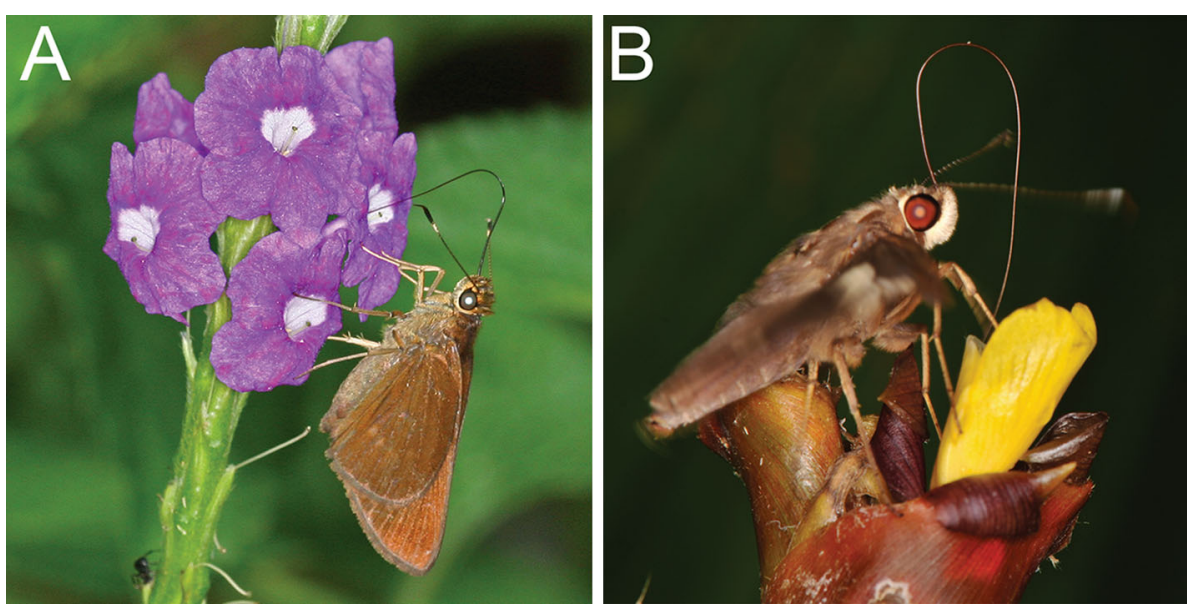


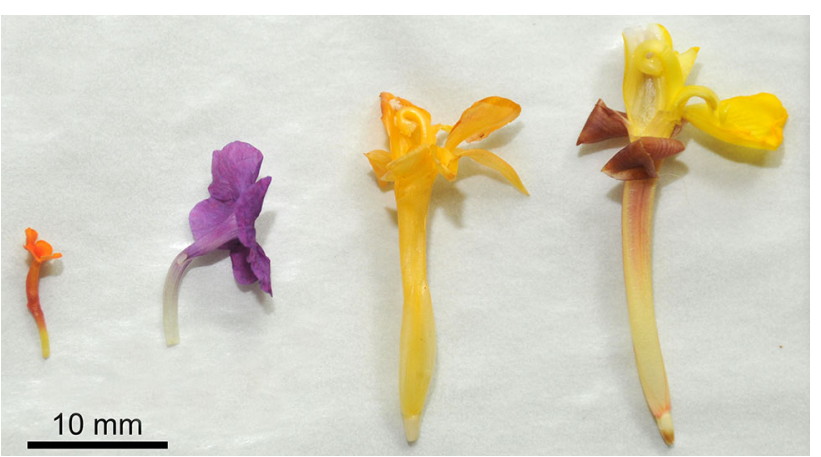

Fig. 2 Flowers of Lantana camara (Verbenaceae), Stachytarpheta frantzii (Verbenaceae), Calathea crotalifera (Marantaceae) and Calathea lutea (Marantaceae) are shown from left to right with increasing corolla length

The yellow-tubed flowers of $C$. crotalifera and C. lutea (Marantaceae, Fig. 2) feature a unique pollination mechanism, which can be easily observed by the naked eye (Fig. 3a, b, also see Bauder et al. 2011, p. 124, Fig. 1b, c). Pollination occurs only when the insect touches a triggerlike appendage of the hooded staminode, which holds the style under tension. The style then springs forward, scrapes off any pollen from the insect and simultaneously places its pollen onto the flower visitor (Pischtschan and ClaßenBockhoff 2008). Each flower has but a single chance to be pollinated and, once triggered, the stylar movement is irreversible. The position of the style after releasement prevents any pollen from subsequently entering the stigma (Kennedy 2000). Since the style movement is easily visible and flowers can be inspected after visitation, we were able to determine whether skippers released the trigger and thus potentially act as efficient pollinators.

To measure corolla lengths, flowers were collected from different plant individuals at several locations in the garden

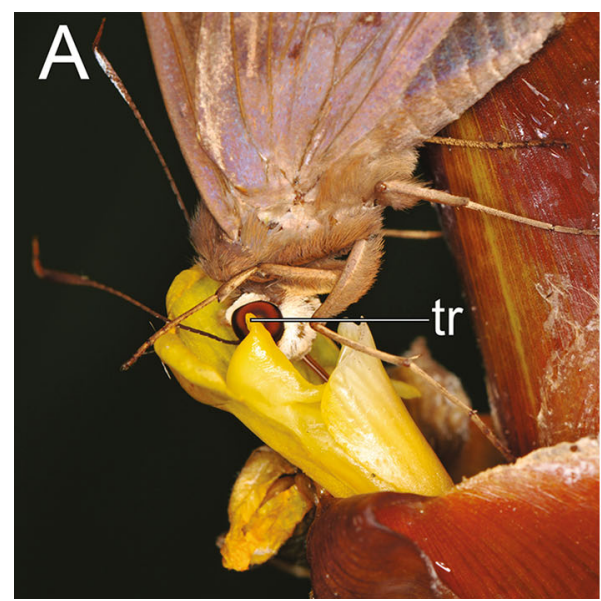

Fig. 3 a The extremely long-proboscid skipper Carystoides escalantei (Hesperiidae) robs nectar from a deep-tubed $C$. lutea flower. Although the butterfly's head is near the entrance of corolla, the trigger appendage of the flower remains untouched. b The extremely of the Tropical Station La Gamba (L. camara: six plants, $S$. frantzii: six plants, $C$. crotalifera: two plants, C. lutea: six plants). Freshly picked flowers were used for estimating corolla length of $L$. camara and $S$. frantzii. Prior to measuring, the slightly curved corolla of each flower was straightened with the aid of a dissection needle. The length of the corolla was measured from the petals to the beginning of the ovaries using a digital caliper. Measurements of ethanol-preserved flowers of $C$. crotalifera and $C$. lutea were performed by A. Ruppel in the course of a diploma thesis (Ruppel 2013). Flowers were photographed with a Nikon D3100 SLR digital camera (Nikon, Tokyo, Japan) equipped with an AF-S DX 18-55 VR objective (Nikon, Tokyo, Japan), and corolla length was measured from the petals to the ovaries (Ruppel 2013) with the software UTHSCSA Image Tool 3.0 (University of Texas, San Antonio, Texas, USA).

\section{Video recordings of flower visits}

Skippers foraging on untriggered flowers of $C$. crotalifera were recorded using a Sony HDR-XR550VE Handycam (Sony Corporation, Tokyo, Japan) in their natural environment (nine interactions) and in an outdoor cage equipped with freshly cut inflorescences (four interactions). Videos were checked for trigger releasement with the software PMB 5.0.02.11130 (Sony Corporation, Tokyo, Japan).

\section{Statistics}

Statistics were calculated with the statistical package IBM SPSS Statistics 21.0 (IBM Corporation, New York, USA). Analyses were done with untransformed data using a Kruskal-Wallis ANOVA. For post hoc tests, Mann-

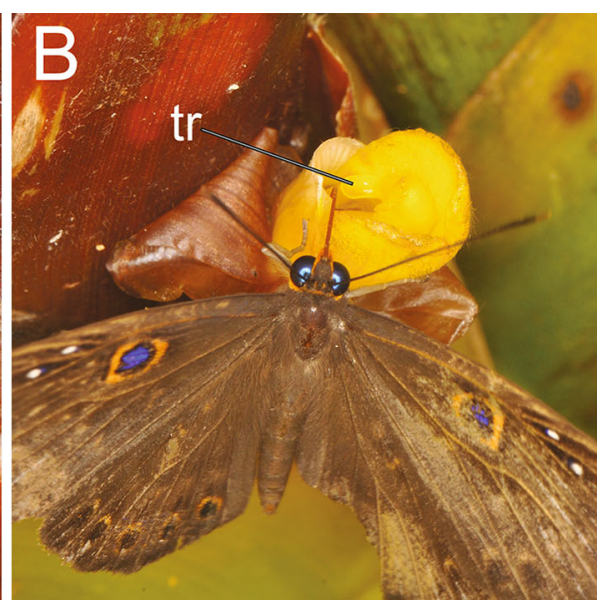

long-proboscid metalmark butterfly Eurybia unxia (Riodinidae) similarly exploits the flower of $C$. lutea without releasing the trigger mechanism and contributing to its pollination. $\mathrm{Tr}-$ trigger appendage 
Whitney $U$ tests (Bonferroni-corrected significance level: $p=0.008$ ) were used. Graphical illustrations were done with SigmaPlot 12.5 (Systat Software Incorporated, San Jose, California, USA), CorelDRAW X6 (Corel Corporation, Munich, Germany) and Adobe Photoshop CS4 Extended 11.0.2 (Adobe Systems Incorporated, San Jose, California, USA).

\section{Results}

A total of 148 individuals of skippers belonging to 45 species and 30 genera were found to visit the flowers of $L$. camara, S. frantzii, C. crotalifera and C. lutea during the period of observation (Table 1). All plant species differed significantly in corolla length $\left(\mathrm{X}^{2}{ }_{(3)}=121.4, p<0.0001\right.$, Table 2). C. lutea had the deepest nectar spurs measuring $31.4 \pm 2.5 \mathrm{~mm}(N=95)$, and those of $C$. crotalifera were $25.0 \pm 1.4 \mathrm{~mm}$ deep $(N=43)$. Nectar spurs of $S$. frantzii measured $16.1 \pm 1.3 \mathrm{~mm}(N=11)$. L. camara had the shortest nectar spurs $(10.4 \pm 0.9 \mathrm{~mm}, N=11)$. Whereas both $L$. camara and $S$. frantzii received frequent visits from other butterflies, e.g., Pieridae, Nymphalidae, Papilionidae and Lycaenidae, the two species of Calathea were visited exclusively by Hesperiidae and butterflies of the genus Eurybia (Riodiniae), confirming the results of a previous study (Bauder et al. 2011).

Proboscis lengths of the skippers differed significantly according to the nectar host plants utilized $\left(X^{2}{ }_{(3)}=96.8\right.$, $p<0.0001$; Fig. 4a). Visitors of L. camara, the flower with the shortest corolla length, had significantly shorter proboscides than the visitors of the other three investigated nectar host plant species (Table 3, Fig. 4a). Visitors of $S$. frantzii were also significantly different from other flower visitors concerning their proboscis length (Table 3, Fig. 4a) and had longer proboscides than the visitors of $L$. camara. Furthermore, the flower visitors of two Calathea species had significantly longer proboscides than visitors of L. camara and S. frantzii (Table 3; Fig. 4a). However, proboscis lengths of skippers that visited $C$. crotalifera and C. lutea were similar (Table 3; Fig. 4a), although the corolla depths of these two plant species differed significantly from each other (Table 2). Generally, skipper butterflies with extremely long proboscides, i.e., longer than $30 \mathrm{~mm}$, visited flowers with deep nectar spurs, and skippers with shorter proboscides used flowers with shorter nectar spurs. Our data show that skippers with extremely long proboscides refrained from visiting short-tubed flowers, since the number of interactions with flowers of different nectar host plant species did not increase with increasing proboscis length (Fig. 4b). Instead, the interaction pattern is compartmentalized, indicating that skipper flower visitors with shorter proboscides are separated from skippers with longer proboscides with respect to their preferred flowers, each using different sets of flowering plants as their source of nectar.

Video recordings of 13 skipper flower visits on untriggered flowers of $C$. crotalifera showed that $92.3 \%$ of the visited flowers, i.e., 12 out of 13 flowers, remained untriggered after the skipper left the flower. During a single flower visit, the skipper released the trigger mechanism with a leg, when at the same time a water droplet fell onto the style of the flower.

\section{Discussion}

Food resource partitioning is held to be a driving force for the coexistence of animals (Hespenheide 1973; Inouye 1980; Ranta and Lundberg 1980; Schoener 1974) and is often estimated using morphological traits, such as size differences between animals or differences in mouthparts in relation to the size of food particles. With respect to nectar-drinking flower visitors, such as butterflies and moths, this refers to differences in mouthpart length. According to this hypothesis of competition avoidance, extremely long-proboscid skippers should specialize in visiting flowers that correspond to their mouthpart lengths and avoid short corolla flowers. Alternatively, since butterflies are regarded as generalist flower visitors (Corbet 2000; Nilsson 1988; Nilsson et al. 1985), the number of plant species available to them could be a function of their proboscis length (Agosta and Janzen 2005). Thus, species with long proboscides could potentially utilize short flowers in addition to long flowers, and it would be expected that the number of flowering species visited would be greater than that of species with short proboscides.

Our data support the hypothesis of competition avoidance, since the extremely long-proboscid skippers generally did not visit flowers with short nectar spurs, such as L. camara or $S$. frantzii, but preferred the deep corolla flowers of the two Calathea species. Both L. camara and $S$. frantzii attract many different flower-visiting insects. These easily accessible flowers are continuously exploited by a great variety of butterfly species possessing rather short proboscides, whereas the long-proboscid skippers are crowded out to deep-tubed flowers, where they can benefit from a more exclusive access to nectar. Further, our observations showed that the deep corollae of Calathea flowers received visits from fewer skipper species (and no visits from other butterflies except for extremely long-proboscid butterflies from the genus Eurybia) than the short corollae of L. camara and S. frantzii. Therefore, extremely long-proboscid Lepidoptera might be released from the level of competition experienced by short-proboscid Lepidoptera (Agosta and Janzen 2005) and choose 
Table 1 Proboscis length and visited flowers of 148 specimens representing 45 species and 30 genera of Hesperiidae

\begin{tabular}{|c|c|c|c|}
\hline Species of Hesperiidae & $N$ & Proboscis length (mm) & Flowers visited \\
\hline \multicolumn{4}{|l|}{ Eudaminae } \\
\hline Astraptes alardus latia (Evans, 1952) & 1 & 23.5 & C. lutea \\
\hline Astraptes anaphus anetta (Evans, 1952) & 1 & 19.5 & S. frantzii \\
\hline Autochton longipennis (Plötz, 1882) & 3 & $17.3 \pm 1.2$ & S. frantzii \\
\hline Autochton zarex (Hübner, 1818) & 2 & $16.3 \pm 1.5$ & S. frantzii \\
\hline Bungalotis quadratum quadratum [Sepp, (1845)] & 1 & 39.4 & C. lutea \\
\hline Cogia calchas (Herrich-Schäffer, 1869) & 3 & $12.3 \pm 0.6$ & $\begin{array}{l}\text { L. } \text { camara }(N=2) \\
\text { S. frantzii }(N=1)\end{array}$ \\
\hline Spathilepia clonius (Cramer, 1775) & 2 & $16.8 \pm 0.2$ & S. frantzii \\
\hline Typhedanus undulatus (Hewitson, 1867) & 1 & 12.4 & L. camara \\
\hline Urbanus procne (Plötz, 1881) & 3 & $15.9 \pm 0.1$ & $\begin{array}{l}\text { S. frantzii }(N=2) \\
\text { L. camara }(N=1)\end{array}$ \\
\hline Urbanus simplicius (Stoll, 1790) & 8 & $16.5 \pm 0.7$ & $\begin{array}{l}\text { L. } \text { camara }(N=6) \\
\text { S. frantzii }(N=2)\end{array}$ \\
\hline Urbanus tanna (Evans 1952) & 7 & $16.7 \pm 0.3$ & $\begin{array}{l}\text { S. frantzii }(N=6) \\
\text { L. camara }(N=1)\end{array}$ \\
\hline Urbanus teleus (Hübner, 1821) & 4 & $16.3 \pm 0.6$ & $\begin{array}{l}\text { L. } \text { camara }(N=3) \\
\text { S. frantzii }(N=1)\end{array}$ \\
\hline \multicolumn{4}{|l|}{ Pyrginae } \\
\hline \multicolumn{4}{|l|}{ Pyrrhopygini } \\
\hline Mysoria ambigua (Mabille and Boullet, 1908) & 4 & $15.3 \pm 0.6$ & $\begin{array}{l}\text { S. frantzii }(N=3) \\
\text { L. camara }(N=1)\end{array}$ \\
\hline \multicolumn{4}{|l|}{ Celaenorrhini } \\
\hline Celaenorrhinus darius (Evans, 1952) & 1 & 29.8 & S. frantzii \\
\hline \multicolumn{4}{|l|}{ Carcharodini } \\
\hline Nisoniades godma (Evans, 1953) & 1 & 10.7 & L. camara \\
\hline \multicolumn{4}{|l|}{ Hesperiinae } \\
\hline \multicolumn{4}{|l|}{ Clade 113} \\
\hline Lycas godart boisduvalii (Ehrmann, 1909) & 1 & 45.7 & C. lutea \\
\hline Perichares adela (Hewitson, 1867) & 8 & $44.5 \pm 4.9$ & $\begin{array}{l}\text { C. } \text { lutea }(N=7) \\
\text { C. } \text { crotalifera }(N=1)\end{array}$ \\
\hline Perichares lotus (A. Butler, 1870) & 1 & 48.3 & C. lutea \\
\hline Pyrrhopygopsis socrates orasus (H. Druce, 1876) & 1 & 34.4 & C. lutea \\
\hline \multicolumn{4}{|l|}{ Calpodini } \\
\hline Aroma henricus henricus (Staudinger, 1876) & 2 & $30.6 \pm 2.0$ & C. crotalifera \\
\hline Calpodes ethlius (Stoll, 1782) & 4 & $42.2 \pm 1.5$ & $\begin{array}{l}\text { C. lutea }(N=3) \\
\text { C. } \text { crotalifera }(N=1)\end{array}$ \\
\hline Carystoides escalantei (H. Freeman, 1969) & 5 & $33.2 \pm 1.5$ & C. lutea \\
\hline Carystoides hondura (Evans, 1955) & 2 & $28.9 \pm 0.3$ & $\begin{array}{l}\text { C. lutea }(N=1) \\
\text { C. } \text { crotalifera }(N=1)\end{array}$ \\
\hline Damas clavus (Herrich-Schäffer, 1869) & 13 & $49.5 \pm 2.4$ & $\begin{array}{l}\text { C. lutea }(N=8) \\
\text { C. } \text { crotalifera }(N=4) \\
\text { L. } \text { camara }(N=1)\end{array}$ \\
\hline Damas immaculata (Nicolay 1973) & 1 & 52.7 & S. frantzii \\
\hline Saliana esperi esperi (Evans 1955) & 2 & $35.9 \pm 2.2$ & $\begin{array}{l}\text { C. lutea }(N=1) \\
\text { C. } \text { crotalifera }(N=1)\end{array}$ \\
\hline Saliana longirostris [Sepp, (1840)] & 1 & 42.7 & C. lutea \\
\hline Saliana salius (Cramer, 1775) & 3 & $47.2 \pm 5.7$ & C. lutea \\
\hline
\end{tabular}


Table 1 continued

\begin{tabular}{|c|c|c|c|}
\hline Species of Hesperiidae & $N$ & Proboscis length (mm) & Flowers visited \\
\hline Saliana severus (Mabille, 1895) & 1 & 51.8 & C. crotalifera \\
\hline Saliana triangularis (Kaye, 1914) & 6 & $41.5 \pm 2.7$ & $\begin{array}{l}\text { C. } \text { crotalifera }(N=5) \\
\text { C. lutea }(N=1)\end{array}$ \\
\hline Talides hispa (Evans, 1955) & 1 & 45.5 & C. lutea \\
\hline Thracides phidon (Cramer, 1779) & 1 & 42.0 & C. lutea \\
\hline Tromba xanthura (Godman, 1901) & 1 & 48.2 & S. frantzii \\
\hline \multicolumn{4}{|l|}{ Anthoptini } \\
\hline Corticea lysias lysias (Plötz, 1883) & 1 & 14.1 & L. camara \\
\hline \multicolumn{4}{|l|}{ Moncini } \\
\hline Arita arita (Schaus, 1902) & 1 & 27.4 & C. crotalifera \\
\hline Cymaenes alumna (A. Butler, 1877) & 2 & $16.5 \pm 1.5$ & L. camara \\
\hline Lerema ancillaris (A. Butler, 1877) & 1 & 20.5 & S. frantzii \\
\hline Morys geisa (Möschler, 1879) & 8 & $20.1 \pm 1.9$ & $\begin{array}{l}\text { S. frantzii }(N=7) \\
\text { L. camara }(N=1)\end{array}$ \\
\hline Morys micythus (Godman, 1900) & 2 & $19.6 \pm 0.8$ & $\begin{array}{l}\text { S. frantzii }(N=1) \\
\text { L. camara }(N=1)\end{array}$ \\
\hline Papias phaeomelas [Hübner, (1831)] & 10 & $17.3 \pm 1.4$ & S. frantzii \\
\hline Papias phainis Godman 1900 & 1 & 16.2 & S. frantzii \\
\hline Papias subcostulata (Herrich-Schäffer, 1870) & 12 & $25.5 \pm 1.4$ & $\begin{array}{l}\text { S. frantzii }(N=11) \\
\text { C. lutea }(N=1)\end{array}$ \\
\hline Vehilius stictomenes illudens (Mabille, 1891) & 2 & $13.0 \pm 0.01$ & L. camara \\
\hline \multicolumn{4}{|l|}{ Hesperiini } \\
\hline Pompeius pompeius (Latreille, [1824]) & 5 & $15.1 \pm 0.3$ & $\begin{array}{l}\text { S. frantzii }(N=4) \\
\text { L. camara }(N=1)\end{array}$ \\
\hline Quinta cannae (Herrich-Schäffer, 1869) & 7 & $21.7 \pm 1.1$ & S. frantzii \\
\hline
\end{tabular}

Mean values \pm standard deviation of proboscis lengths are given, whenever more than one individual per species was measured. When two or more plant species were visited by individual butterflies of one species, the number of observed flower visits to each plant species is given in parentheses

Table 2 Pairwise post hoc tests (Mann-Whitney $U$ tests, $p<0.008$; Bonferronicorrected) showed that all nectar host plants differ significantly in corolla length

\begin{tabular}{llll}
\hline Corolla length of host plants $(\mathrm{mm})$ & L. camara & S. frantzii & C. crotalifera \\
\hline L. camara $(10.2,8.4-11.6)$ & - & - & - \\
S. frantzii $(15.7,14.6-18.1)$ & $p<0.0001^{*}$ & - & - \\
C. crotalifera $(25.2,22.2-28.3)$ & $p<0.0001^{*}$ & $p<0.0001^{*}$ & - \\
C. lutea $(31.2,26.5-36.2)$ & $p<0.0001^{*}$ & $p<0.0001^{*}$ & $p<0.0001^{*}$ \\
\hline
\end{tabular}

Median, minimal and maximal corolla length of each nectar host plant are given in brackets deep-tubed flowers, which cannot be used by short-proboscid butterflies. The same was confirmed earlier for British butterfly assemblages (Porter et al. 1992; Corbet 2000). Furthermore, extremely long-proboscid skippers did not discriminate between the flowers of $C$. crotalifera and $C$. lutea, probably because these flowers look alike regarding their floral morphology and color and grow in the same habitats (Ruppel 2013).
Extremely long-proboscid skippers, such as the calpodines (Hesperiinae), are known to live in shady, forested habitats (Warren et al. 2009). Calathea plants usually grow in the understory of the forest (Weber et al. 2001), and thus probably have similar habitat requirements as extremely long-proboscid skippers. Because of this, we hypothesize that extremely long-proboscid skippers make the best of their situation by using nectar plants flowering 


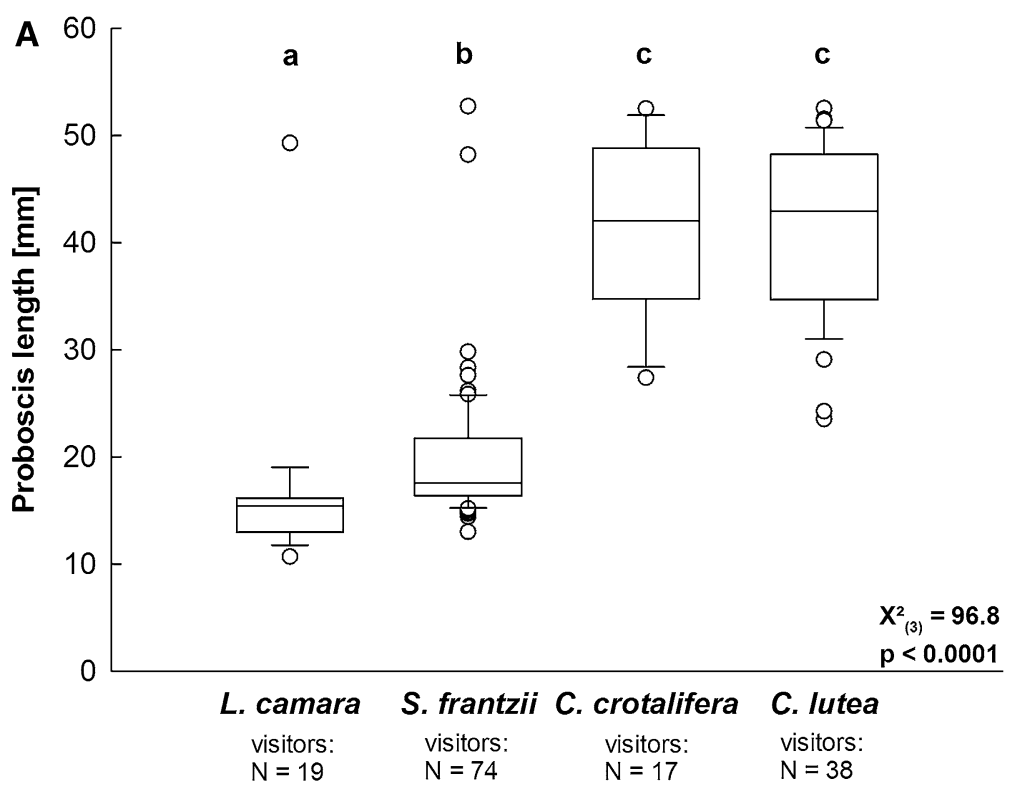

B

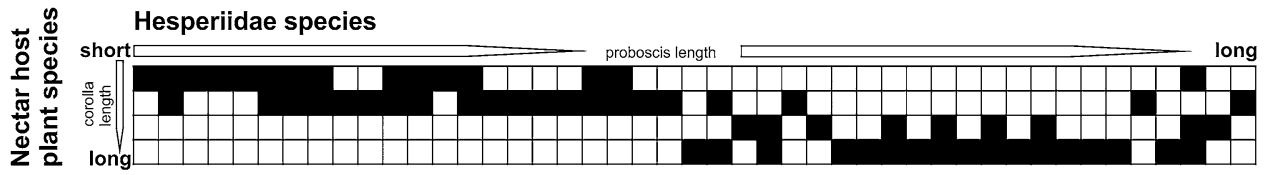

Fig. 4 a Flower use by Hesperiidae differed significantly according to proboscis length $\left(\mathrm{X}^{2}{ }_{(3)}=96.8, p<0.0001\right)$. Hesperiidae having long proboscides visited flowers with deep nectar spurs. Although the corolla length of all nectar host plant species differed significantly, proboscis length of Hesperiidae that visited C. crotalifera and C. lutea did not differ significantly (post hoc tests: Mann-Whitney $U$ tests, different letters above boxplots represent significant differences at

Table 3 Pairwise post hoc tests (Mann-Whitney $U$ tests, $p<0.008$; Bonferroni-corrected) showed that each nectar host plant is visited by a distinct set of skippers that differ significantly in proboscis length. $p<0.008$; Bonferroni-corrected). b Binary interaction matrix (presence or absence of flower visits) of skipper species (columns) and plant species (rows) ranked according to mean proboscis length or mean corolla length, respectively. Increasing proboscis length did not increase the number of visited plant species. Short- and longproboscid skippers each used a different set of flowering plants

Only visitors of $C$. crotalifera and $C$. lutea did not differ significantly in proboscis length

\begin{tabular}{llll}
\hline Proboscis length of skippers $(\mathrm{mm})$ & L. camara & S. frantzii & C. crotalifera \\
\hline L. camara $(15.4,10.7-49.3)$ & - & - & - \\
S. frantzii $(17.6,13.0-52.7)$ & $p<0.0001^{*}$ & - & - \\
C. crotalifera $(42.1,27.4-52.5)$ & $p<0.0001^{*}$ & $p<0.0001^{*}$ & - \\
C. lutea $(42.9,23.5-52.5)$ & $p<0.0001^{*}$ & $p<0.0001^{*}$ & $p=0.85$ \\
\hline
\end{tabular}

Median, minimal and maximal proboscis length of visitors of each nectar host plant are given in brackets

in their proximity and harvesting plenty of nectar out of deep tubes. Furthermore, the larvae of many long-proboscid skipper species, such as representatives of the Calpodini, feed on monocotyledons (Janzen and Hallwachs 2009) that occur in the understory of the forest (Weber et al. 2001), including Marantaceae (Calathea sp., Maranta sp., Thalia sp.), Costaceae (Costus sp.), Heliconiaceae (Heliconia sp.) and Zingiberaceae (Renealmia sp.) (Janzen and Hallwachs 2009). Therefore, adult butterflies would search for these plants to lay their eggs anyway and would simultaneously have the opportunity to take nectar from the deep-tubed flowers of the larval host plants.

Many studies have demonstrated a close match between flower and pollinator morphology, such as correlations between proboscis length of pollinators and corolla depth of flowers on the scale of species-specific interactions, that have served as supposed examples of coevolution (Alexandersson and Johnson 2002; Grant and Grant 1965, 1983; Harder 1985; Johnson and Steiner 1997; Nilsson 1988, 1998; Nilsson et al. 1985). Although our results 
showed that the proboscis lengths of skipper butterflies differed significantly between the visited flower species, we did not observe a close match between extremely long proboscides and deep tubes: Extremely long-proboscid skipper butterflies that used $C$. crotalifera and $C$. lutea as nectar source had a mean proboscis length of $43.4 \mathrm{~mm}$, exceeding the corolla length of $C$. crotalifera by $18.4 \mathrm{~mm}$ and $C$. lutea by $12 \mathrm{~mm}$. Similarly, the proboscides of $E$. lycisca butterflies in Costa Rica that fed on the nectar of $C$. crotalifera and $C$. lutea plants measured $36.5 \mathrm{~mm}$ on average (Bauder et al. 2011), exceeding the corolla depth of C. crotalifera and C. lutea by 11.5 or $5.1 \mathrm{~mm}$, respectively. Since the butterflies' proboscides are longer than the floral tube, they are not forced to plunge their head into the corolla entrance and successful pollination is very unlikely.

Apart from that, previous analyses on the flower-visiting behavior of extremely long-proboscid butterflies (Bauder et al. 2011) as well as the results of this study demonstrate that neither skipper nor metalmark butterflies were able to release the trigger mechanism of Calathea-flowers effectively. Schemske and Horvitz (1984) made similar observations and stated that while Hesperiidae accounted for $21 \%$ of all flower visits on Calathea ovandensis, they were responsible for only $2 \%$ of all triggered flowers and less than $1 \%$ of all fruit sets. By contrast, their legitimate pollinators, the euglossine bees (Borrell 2005; Janzen 1971) achieved $99 \%$ of all fruit sets due to an eightfold greater efficiency in style releasement and fruitset of triggered flowers (Schemske and Horvitz 1984). Euglossine bees feature long proboscides ranging between 13.8 and $38.9 \mathrm{~mm}$ length (Borrell 2005) and are regarded as generalistic flower visitors, because the number of visited plant species increases with proboscis length (Borrell 2005). These results raise the questions why these deep-tubed flowers have specialized on generalistic bees (Borrell 2005) and how nectar-thieving butterflies fit into this network.

Schemske (1981) and Borrell (2005) hypothesized that many steady-state understory plants, such as Calathea or Costus, are unable to support the energetic needs of an entire pollinator population because of their low density, the small size of some species and few flowers blooming simultaneously (Janzen 1971). They argued that increasing nectar production would be energetically costly, but by morphologically excluding short-proboscid insects as potential nectar consumers, these plants can still provide plenty of nectar to individual euglossine bees, which learn to include these profitable flowers in the same nectar traplines daily (Borrell 2005; Janzen 1971). If that is true, the long nectar spurs of Calathea plants could have evolved not via directional selection exerted by a specialized pollinator (Darwin 1862), but by competition among sympatric flowers for inclusion on a pollinator's foraging route (Garrison and Gass 1999).
Nectar-thieving butterflies would ransack Calathea nectar stores, leaving less nectar for pollinating Euglossini. The average nectar amount that an extremely long-proboscid skipper butterfly could take up during a flower visit is roughly estimated at $7.1 \mu \mathrm{l}$ (Bauder et al. 2015; amount of ingested nectar was calculated by multiplying the average nectar intake rate of skippers that visited Calathea flowers with the average suction time on $C$. crotalifera flowers). Given that the average nectar amount of a flower belonging to the genus Calathea measures about $14.4 \mu \mathrm{l}$ (Ruppel 2013), a skipper butterfly could empty half of a flower's nectar reserves in a single visit. Since extremely long-proboscid butterflies are abundant visitors of Calathea, as can be inferred from the observations of Schemske and Horvitz (1984), who accounted $21 \%$ of all flower visits to Hesperiidae, they can be assumed to have a serious impact on the nectar availability for the legitimate pollinators of Calathea plants. In this way, long-proboscid butterflies could deteriorate the reproduction of Calathea. Furthermore, these plants not only suffer from nectar robbery by extremely long-proboscid skipper and metalmark butterflies, but also from flower predation exerted by the larvae of Eurybia butterflies, which feed on Calathea flowers and not on foliage (DeVries 1997; Horvitz et al. 1987).

Acknowledgments We wish to thank the Tropical Research Station La Gamba for providing laboratory facilities and the Costa Rican Ministerio del Ambiente y Energía for kindly granting research permits. We are grateful to Martin Hepner for his enthusiastic support during field observations. We thank Martin Hepner and Philipp Figueora for taking images of skippers and plants. We thank Alexander Ruppel for providing us with corolla length data of Calathea plants, and John Plant for correcting the English manuscript. Further, we are grateful to Konrad Fiedler for helpful suggestions. The study was funded by the Austrian Science Fund (P 22248 B17).

Open Access This article is distributed under the terms of the Creative Commons Attribution 4.0 International License (http:// creativecommons.org/licenses/by/4.0/), which permits unrestricted use, distribution, and reproduction in any medium, provided you give appropriate credit to the original author(s) and the source, provide a link to the Creative Commons license, and indicate if changes were made.

\section{References}

Agosta SJ, Janzen DH (2005) Body size distributions of large Costa Rican dry forest moths and the underlying relationship between plant and pollinator morphology. Oikos 108:183-193. doi:10. 1111/j.0030-1299.2005.13504.x

Alexandersson R, Johnson SD (2002) Pollinator-mediated selection on flower-tube length in a hawkmoth-pollinated Gladiolus (Iridaceae). Proc R Soc Lond B 269:631-636. doi:10.1098/rspb. 2001.1928

Bauder JAS, Lieskonig NR, Krenn HW (2011) The extremely longtongued Neotropical butterfly Eurybia lycisca (Riodinidae): 
proboscis morphology and flower handling. Arthropod Struct Dev 40:122-127. doi:10.1016/j.asd.2010.11.002

Bauder JAS, Morawetz L, Warren AD, Krenn HW (2015) Functional constraints on the evolution of long butterfly proboscides: lessons from Neotropical skippers (Lepidoptera: Hesperiidae). J Evol Biol 28:678-687. doi:10.1111/jeb.12601

Borrell BJ (2005) Long tongues and loose niches: evolution of euglossine bees and their nectar flowers. Biotropica 37:664-669. doi:10.1111/j.1744-7429.2005.00084.x

Corbet SA (2000) Butterfly nectaring flowers: butterfly morphology and flower form. Entomol Exp Appl 96:289-298. doi:10.1046/j. 1570-7458.2000.00708.x

Courtney SP, Hill CJ, Westerman A (1982) Pollen carried for long periods by butterflies. Oikos 38:260-263. doi:10.2307/3544030

Darwin C (1862) On the various contrivances by which British and foreign orchids are fertilised by insects and on the good effects of intercrossing. John Murray, London

DeVries PJ (1997) The butterflies of Costa Rica and their natural history-volume II: Riodinidae. Princeton University Press, Chichester

Garrison JSE, Gass CL (1999) Response of a traplining hummingbird to changes in nectar availability. Behav Ecol 10:714-725. doi:10.1093/beheco/10.6.714

Gilbert LE (1972) Pollen feeding and reproductive biology of Heliconius butterflies. PNAS 69:1403-1407. doi:10.1073/pnas. 69.6.1403

Gilbert LE (1975) Ecological consequences of a coevolved mutualism between butterflies and plants. In: Gilbert LE, Raven PH (eds) Coevolution of animals and plants. University of Texas Press, Austin, pp 210-240

Grant V, Grant KA (1965) Flower pollination in the Phlox family. Columbia University Press, New York

Grant V, Grant KA (1983) Hawkmoth pollination of Mirabilis longiflora (Nyctaginaceae). PNAS 80:1298-1299. doi:10.1073/ pnas.80.5.1298

Harder LD (1985) Morphology as a predictor of flower choice by bumble bees. Ecology 66:198-210. doi:10.2307/1941320

Hespenheide HA (1973) Ecological inferences from morphological data. Annu Rev Ecol Evol Syst 4:213-229. doi:10.1146/annurev. es.04.110173.001241

Horvitz CC, Turnbull C, Harvey DJ (1987) Biology of immature Eurybia elvina (Lepidoptera: Riodinidae), a myrmecophilous metalmark butterfly. Entomol Soc Am 80:513-519

Inouye DW (1980) The effect of proboscis and corolla tube lengths on patterns and rates of flower visitation by bumblebees. Oecologia 45:197-201. doi:10.1007/BF00346460

Janzen DH (1971) Euglossine bees as long-distance pollinators of tropical plants. Science 171:203-205. doi:10.1126/science.171. 3967.203

Janzen DH, Hallwachs W (2009) Dynamic database for an inventory of the macrocaterpillar fauna, and its food plants and parasitoids, of area de conservacion guanacaste (ACG), northwestern Costa Rica (nn-SRNP-nnnnn voucher codes). URL http://janzen.sas. upenn.edu

Johnson SD (1997) Pollination ecotypes of Satyrium hallackii (Orchidaceae) in South Africa. Bot J Linn Soc 123:225-235. doi:10.1006/bojl.1996.0082

Johnson SD, Anderson B (2010) Coevolution between food-rewarding flowers and their pollinators. Evol: Educ Outreach 3:32-39. doi:10.1007/s12052-009-0192-6

Johnson SD, Steiner KE (1997) Long-tongued fly pollination and evolution of floral spur length in the Disa draconis complex (Orchidaceae). Evolution 51:45-53. doi:10.2307/2410959

Kennedy H (2000) Diversification in pollination mechanisms in the Marantaceae. In: Wilson K, Morrison D (eds) Monocots: systematics and evolution. CSIRO Publishing, Collingwood, pp 335-344

Krenn HW (2010) Feeding mechanisms of adult Lepidoptera: structure, function, and evolution of the mouthparts. Annu Rev Entomol 55:307-327. doi:10.1146/annurev-ento-112408-085338

Krenn HW, Wiemers M, Maurer L, Pemmer V, Huber W, Weissenhofer A (2010) Butterflies of the Golfo Dulce region, Costa Rica. Verein zur Förderung der Tropenstation La Gamba, Vienna

Levin DA, Berube DE (1972) Phlox and Colias: the efficiency of a pollination system. Evolution 26:242-250. doi:10.2307/2407034

Muchhala N, Thomson JD (2009) Going to great lengths: selection for long corolla tubes in an extremely specialized bat-flower mutualism. Proc R Soc B 276:2147-2152. doi:10.1098/rspb. 2009.0102

Nilsson LA (1988) The evolution of flowers with deep corolla tubes. Nature 334:147-149. doi:10.1038/334147a0

Nilsson LA (1998) Deep flower for long tongues. Tree 13:259-260. doi:10.1016/S0169-5347(98)01452-9

Nilsson LA, Jonsson L, Rason L, Randrianjohany E (1985) Monophily and pollination mechanisms in Angraecum arachnites Schltr. (Orchidaceae) in a guild of long-tongued hawkmoths (Sphingidae) in Madagascar. Biol J Linn Soc 26:1-19. doi:10.1111/j.1095-8312.1985.tb01549.x

Pauw A, Stofberg J, Waterman RJ (2009) Flies and flowers in Darwin's race. Evolution 63:268-279. doi:10.1111/j.1558-5646. 2008.00547.x0014-3820

Pischtschan E, Claßen-Bockhoff R (2008) Setting-up tension in the style of Marantaceae. Plant Biol 10:441-450. doi:10.1111/j. 1438-8677.2008.00051.x

Porter K, Steel CA, Thomas JA (1992) Butterflies and communities. In: Dennis RLH (ed) The ecology of butterflies in Britain. Oxford University Press, Oxford, pp 46-72

Ranta E, Lundberg H (1980) Resource partitioning in bumblebees: the significance of differences in proboscis length. Oikos 35:298-302. doi: $10.2307 / 3544643$

Rodríguez-Gironés MA, Llandres AL (2008) Resource competition triggers the co-evolution of long tongues and deep corolla tubes. PLoS ONE 3:1-8. doi:10.1371/journal.pone.0002992

Rodríguez-Gironés MA, Santamaría L (2007) Resource competition, character displacement, and the evolution of deep corolla tubes. Am Nat 170:455-464. doi:10.1086/520121

Ruppel A (2013) Morphologisch-systematische Untersuchungen der Blüten der Marantaceae im Piedras Blancas NP, Costa Rica. Diploma thesis, Justus-Liebig Universität Gießen

Schemske DW (1981) Floral convergence and pollinator sharing in two bee-pollinated tropical herbs. Ecology 62:946-954. doi:10. $2307 / 1936993$

Schemske DW, Horvitz CC (1984) Variation among floral visitors in pollination ability: a precondition for mutualism specialization. Science 225:519-521. doi:10.1126/science.225.4661.519

Schoener TW (1974) Resource partitioning in ecological communities. Science 185:27-39. doi:10.1126/science.185.4145.27

Shreeve TG (1992) Adult behaviour. In: Dennis RLH (ed) The ecology of butterflies in Britain. Oxford University Press, Oxford, pp 22-45

Stefanescu C, Traveset A (2009) Factors influencing the degree of generalization in flower use by Mediterranean butterflies. Oikos 118:1109-1117. doi:10.1111/j.1600-0706.2009.17274.x

Tiple AD, Kuhrad AM, Dennis RLH (2009) Adult butterfly feedingnectar flower associations: constraints of taxonomic affiliation, butterfly, and nectar flower morphology. J Nat Hist 43:855-884. doi:10.1080/00222930802610568

Tudor O, Dennis RLH, Greatorex-Davies JN, Sparks TH (2004) Flower preferences of woodland butterflies in the UK: nectaring 
specialists are species of conservation concern. Biol Conserv 119:397-403. doi:10.1016/j.biocon.2004.01.002

Warren AD, Ogawa JR, Brower AVZ (2009) Revised classification of the family Hesperiidae (Lepidoptera: Hesperioidea) based on combined molecular and morphological data. Sys Entomol 34:467-523. doi:10.1111/j.1365-3113.2008.00463.x

Wasserthal LT (1997) The pollinators of the Malagasy star orchids Angraecum sesquipedale, A. sororium and A. compactum and the evolution of extremely long spurs by pollinator shift. Bot Acta 110:343-359. doi:10.1111/j.1438-8677.1997.tb00650.x

Wasserthal LT (1998) Deep flowers for long tongues. Tree 13:459-460. doi:10.1016/S0169-5347(98)01481-5

Weber A, Huber W, Weissenhofer N, Zamora N, Zimmermann G (2001) An introductory field guide to the flowering plants of the
Golfo Dulce rain forests, Costa Rica. Corcovado National Park and Piedras Blancas National Park ("Regenwald der Österreicher"). Stapfia 78, Linz

Whittall JB, Hodges SA (2007) Pollinator shifts drive increasingly long nectar spurs in columbine flowers. Nature 447:706-710. doi:10.1038/nature 05857

Wiklund C (1981) On the pollination efficiency of butterflies: a reply to Courtney et al. Oikos 38:263. doi:10.2307/3544031

Wiklund C, Eriksson T, Lundberg H (1979) The wood white butterfly Leptidea sinapis and its nectar plants: a case of mutualism or parasitism? Oikos 33:358-362. doi:10.2307/3544323

Woodson RE Jr, Schery RW, Moldenke HN (1973) Flora of Panama. Part IX. family 168. Verbenaceae. Ann Mo Bot Gard 60:41-148. doi: $10.2307 / 2394768$ 